Stanisław Radoń*

Kraków

\title{
Cechy osobowości a przeżycia religijne młodzieży artystycznej
}

Określenie osobowości jest jednym z ważnych zadań, które stoją przed psychologia, która jest z jednej strony nauką humanistyczną, a z drugiej empiryczną. Jedną z metod określania struktury osobowości jest zastosowanie technik psychometrycznych. U podstaw stosowanych powszechnie w psychologii metod psychometrycznych leżą ogólne koncepcje osobowości opracowane przez klasyków psychologii: Allporta, Cattella i Eysencka. Opowiadają się oni za dwoma stanowiskami (Chlewiński, 1987): 1) idiograficznym (Allport), które negatywnie ustosunkowując się do analitycznych metod stosowanych w psychologii empirycznej zmierza do wykrywania ogólnych prawidłowości (człowiek „ogólny” - charakterystyka osobowości wyabstrahowanej z indywidualności). Wprawdzie uznaje sensowność określania „,eech wspólnych" różnych osobowości oraz dokonywania porównań między jednostkami czy grupami osób, ale w ograniczonym sensie. Podkreśla złożoność i jedyność ludzkiego myślenia, odczuwania i działania oraz docenia kluczową rolę świadomej motywacji (w przeciwieństwie do behawioralnych i psychoanalitycznych modeli osobowości), oraz 2) nomotetycznym (Cattell, Eysenck), które wychodzą z założenia, że bardziej istotną rzeczą jest rzetelność oceniania różnych aspektów osobowości niż

* Ks. Stanisław Radoń, dr (PAT), teolog i psychoterapeuta. Nauczyciel dyplomowany Zespołu Państwowych Szkół Plastycznych w Krakowie, wykładowca w Podyplomowym Studium dla Nauczycieli w Krakowie. Ukończył studia teologiczne na Papieskiej Akademii Teologicznej, a psychologiczne na Katolickim Uniwersytecie Lubelskim (Podyplomowe Studium Psychoterapii i Poradnictwa Psychologicznego). Odbył praktykę psychologiczną w Katedrze Psychiatrii Collegium Medicum Uniwersytetu Jagiellońskiego. Autor książki Religijność potencjalnych artystów $w$ kontekście preferowanych wartości (1999) i współautor Przeżycia religijne młodzieży uzdolnionej artystycznie (2006). 
jego ostateczna trafność. Cattell i Eysenck przy pomocy zaawansowanych technik statystycznych (analiza czynnikowa) stworzyli czynnikowe modele osobowości.

Przedstawione modele nie są ze sobą z zasadniczej kolizji. W pracy tej opowiedziano się za drugim stanowiskiem oraz proponowanym modelem Eysencka. Posługiwał się on procedurą odmienną od Cattella, która doprowadziła go do małej liczby czynników osobowości (u Cattella - duża liczba czynników - tzw. teoria cech). Zdaniem Eysencka, typy są bardziej podstawowe niż cechy ponieważ, jak twierdzi badacz, u podstaw cech leżą jeszcze bardziej podstawowe konstrukty (abstrakcyjne wymiary matematyczne, których status metodologiczny jest podobny np. do pojęcia elektronu w fizyce). Pomiędzy cechami występują różne czynniki pośredniczące wyższego rzędu, które metodami statystycznymi można wychwycić upraszczając w poważnym stopniu procedurę - nie trafność - badawczą. Mnożenie czynników - zdaniem Eysencka - nie służy pogłębieniu trafności, wprowadza natomiast niepotrzebny balast denotacyjny. Poznanie człowieka, jest tak skomplikowane, a metody stosowane w psychologii sa obecnie mało godne zaufania, że uproszczenie metod badawczych - uważa badacz i teoretyk - za korzystne (Chlewiński, 1987).

Eysenck $(1947,1969)$, autor tzw. teorii typów, na podstawie przeprowadzonych badań i analiz statystycznych, opracował ostatecznie trójczynnikowy model osobowości, na który składają się trzy różne wymiary: psychotyzm $(\mathrm{P})$, neurotyzm $(\mathrm{N})$ i intro-ekstrawersja (E). Te wymiary stanowią różne aspekty osobowości człowieka, których nie można już sprowadzić do bardziej podstawowych (trójwymiarowa przestrzeń matematyczna). Cechy osobowości - to według definicji Eysencka - nawykowe reakcje, które na wyższym poziomie organizacji w pewnych grupach tworząc wzajemne powiązania tj. typy, czyli trzy wymiary.

Psychotyzm inaczej „twardość myślenia” (nieelastyczność, sztywność - z ang. tough-minded - termin wprowadzony w późniejszych opracowaniach) - w rozumieniu Eysnecków - jest zbieżny z anstysocjalnością, czyli tym, co dawniej określano mianem „psychopatii” czy „socjopatii”. Psychotyzm nie ma nic wspólnego z psychozą (psychotycy mają niskie nasilenie tej cechy osobowości). Psychotyzm określa człowieka samotnego, nigdzie nie zadomowionego, nie zważającego na ludzi, zimnego i wyrachowanego. Taki człowiek jest całkowicie nieczuły i już od dziecka wykazuje zanik uczuć empatycznych. Ponadto wykazuje skrajny brak kontroli emocji, zwłaszcza agresji, bywa złośliwy, nawet wobec tych, których kocha. „Często bawi się kosztem innych ludzi, specjalizując się w wyprowadzaniu ich z równowagi” (Pospiszyl, 1992, s. 207).

Neurotyzm określa osoby labilne uczuciowo, o niskim progu wrażliwości a wysokiej reaktywności, skłonne do silnego i trwałego reagowania na klasę bodźców działających na układ sympatyczny (pobudzający i wzmacniający reakcje). Taka skłonność uważana jest za wrodzoną (o podłożu fizjologicznym) dyspozycję organizmu. Neurotyzm diagnozuje następujące aspekty psychologiczne: nieśmiałość i inne trudności w kontaktach interpersonalnych, zależność od innych, nierównomierność osiagnięć zawodowych, skłonność do zamartwiania się, łatwość urażania uczuć, brak zaufania 
we własne siły, poczucie niższości, pobudliwość, bezsenność, dokuczliwe i przykre sny, dolegliwości zdrowotne (np. bóle i zawroty głowy, kłopoty żołądkowe itd.).

Ekstra-introwersja wyraża kontinuum od skrajnej introwersji do ekstrawersji (jedna cecha o dwóch skrajnych biegunach). Eysenck uważa, że również ten wymiar, podobnie jak neurotyzm, zależy w znacznym stopniu od podstaw wrodzonych i mają podobne podłoże fizjologiczne (ekstra-introwersja dają się mierzyć podobnymi a nawet tymi samymi wskaźnikami na skali pobudzenie-hamowanie, odnoszą się zasadniczo do różnic w zakresie towarzyskości i impulsywności). Introwertyk i ekstrawertyk różnią się w zakresie reagowania: u ekstrawertyka występuje przewaga procesów pobudzania na procesami hamowania (układ sympatyczny), a u introwertyka przewaga procesów hamowania nad pobudzania (układ parasympatyczny). Typowy ekstrawertyk jest towarzyski, radosny, aktywny, ma wielu przyjaciół, działa pod wpływem chwili, łatwo się nudzi, a więc uwielbia momenty pobudzenia (niski poziom aktywacji). Natomiast introwertyk jest spokojny, refleksyjny, nastawiony do wewnątrz, ale za to bardziej niż ekstrawertyk wrażliwy jest na ból, szybciej się męczy, gorzej wypada w momentach pobudzenia (np. egzaminy w szkole).

Przeprowadzono stosunkowo dużo badań dotyczących związku pomiędzy rozmaitymi cechami osobowości a postawami religijnymi (religijnością). Zasadniczym przedmiotem tych badań były korelaty albo uwarunkowania religijności. Tym zagadnieniem zajmowali się różni badacze: Batson, Schoenrade, Ventis (1993), Hood, Spilka, Hunsberger, Lietar (1996), Paloutzian (1996). W Polsce tym tematem zajmowali się głównie Bazylak (1984), Chlewiński (1973, 1976, 1981, 1987), Prężyna (1981). W swych badaniach stosowali kwestionariusze Cattella 16-czynnikowy i Eysencka 3-czynnikowy.

Osobną dziedzinę stanowi temat powiązań pomiędzy przeżyciami religijnymi (subiektywny aspekt postawy religijnej obejmujący takie obszary jak uczucia religijne, doświadczenia religijne typu mistycznego) a różnymi aspektami osobowości. Najbardziej zasłużonym badaczem dokonującym naukowych eksploracji dotyczących powiązań pomiędzy przeżyciami religijnymi a cechami osobowości jest Hood $(1975,1995,1996,2001)$. W Polsce tym zagadnieniem zajmowali się tacy autorzy jak: Głaz (1995, 1996, 2003, 2004), Radoń, Głaz, (2006), Szymołon (1998).

Niektóre badania dotyczące powiązań pomiędzy cechami osobowości a przeżyciami religijnymi ujawniają, że osoby o introwersyjnych cechach osobowości, refleksyjne, zdolne do wglądu, autorefleksji, są bardziej skłonne do przeżyć religijnych niż ekstrawersyjne (współzależność korelacyjna - por. Mercer, Durham, 1999). Wyniki sugerują bardzo wyraźnie, że skrajne nasilenie ekstrawersji nie wpływa na intensywność przeżyć religijnych. Wyniki innych badań tj. polskich (Radoń, Głaz, 2006) nie stoją w sprzeczności z wynikami tamtych badań, ponieważ ujawniły, że najwyższy poziom przeżyć religijnych jest w grupie osób o bogatej strukturze osobowości (podwyższone nasilenie introwersji współwystępujące $\mathrm{z}$ wysokim poziomem psychotyzmu - tzw. grupa artystyczna o cechach twórczych). Należy jednak stwierdzić, że wyniki badań dotyczące korelatów osobowościowych referowanych doświadczeń nie są spójne. Wyniki innych badań wykazały bowiem brak istotnych związków po- 
między cechami osobowości a nasileniem przeżyć religijnych (por. Alexander i in., 1978; Caird, 1987).

Wyniki badań uzyskane w Polsce na specyficznej, bo artystycznej grupie młodzieży, ujawniły, że istotny wpływ na dynamikę przeżyć religijnych wywiera nie introwersja, ale ekstrawersja (szczególnie u mężczyzn: otwartość, towarzyskość, spontaniczność, podczas gdy u kobiet psychotyzm związany z „twardością myślenia”, które - zgodnie z tezami psychologii twórczości - cechuje osoby twórcze. Wyniki niektórych badań dotyczących mężczyzn (Francis, Thomas, 2005) potwierdzają tę tezę, ukazując pozytywną korelację pomiędzy orientacją mistyczną a ekstrawersją (brak powiązań z neurotyzmem i psychotyzmem). Wyniki innych badań (Capps, 1999; Schlesing, 2005) potwierdzają ten wniosek badawczy pod innym względem ukazując, że takie korelaty ekstrawersji jak tendencje do przebojowości i odważnego odkrywania duchowej tożsamości świadczą o zdolności do przeżyć mistycznych (występują one szczególnie w świeckich i religijnych rites de passages lub peak experiences poprzez nawiązanie relacji z innymi oraz „Większą siłą”).

Elitarny charakter zjawiska przeżyć religijnych z jednej strony powoduje brak systematycznych badań dotyczących uwarunkowań osobowościowych referowanych doświadczeń a z drugiej strony wymaga stosowania metod raczej idiograficznych, a to nie służy szybkiemu poszerzaniu wiedzy na temat uwarunkowań osobowościowych. Ponadto, jak widać z przedstawionych wyników badań nie wynika jakiś spójny wniosek dotyczący korelatów osobowościowych przeżyć religijnych (najsilniejsze przeżycia religijne występują u osób introwersyjnych, ale ich intensywność zależy od tendencji ekstrawersyjnych).

Wychodząc z założenia, że przeżycia religijne mogą być powiązane w różny sposób z cechami osobowości, podjęto próbę weryfikacji tez o osobowościowych uwarunkowaniach przeżyć religijnych. W związku z aktualnością problematyki osobowościowych uwarunkowań przeżyć mistycznych podjęto próbę analizy tego obszaru badawczego.

Celem pracy będzie odpowiedź na następujące pytania badawcze:

1. Czy zmienna niezależna, jakq sq cechy osobowości wptywaja istotnie na nasilenie różnych aspektów przeżyć religijnych?

2. Jaki rodzaj $i$ w jakim stopniu zmienne niezależne dotyczace różnych cech osobowości wyjaśniaja wariancje zmiennej zależnej tj. przeżyć religijnych?

W stosunku do tak postawionych pytań wysunięto następujące hipotezy badawcze:

1. Nasilenie cech osobowości wptywa istotnie na dynamike przeżyć religijnych we wszystkich wymiarach.

2. Wszystkie wymiary osobowości wywieraja istotny wpływ na przeżycia religijne młodzieży artystycznej. 


\section{Metody badawcze}

Ukazanie powiązań jednych aspektów osobowości z drugimi wymaga odpowiednich narzędzi badawczych. Dobór ich zależy od postawionego problemu do rozstrzygnięcia, jak i od zamierzonego celu pracy. Wybrano takie narzędzia, za pomocą których można określić cechy osobowości i przeżycia religijne wybranej próbki badanych osób. W wyborze kierowano się głównie względami psychometrycznymi (techniki te są standaryzowane i zostały dzięki wcześniejszym badaniom adoptowane do populacji polskiej).

A. Zrewidowany Inwentarz Osobowości (ZIO) H. Eysencka. Narzędzie badawcze w polskiej wersji (Eysenck Personality Questionnaire-Revised) ma w psychologii polskiej dużą popularność, tak jak teoria osobowości i inne inwentarze Eysencka. Polska adaptacja jest użytecznym narzędziem badawczym, o właściwościach psychometrycznych niewiele odbiegających od oryginału (trafność od 0,50 do 0,85, stabilność - od 0,59 do 0,82) (Drwal, 1995). Składa się z 90 pytań, na które odpowiada się tak lub nie i posiada odpowiednią skalę stenową do obliczania wyników (są normy polskie).

Inwentarz w tej wersji mierzy cztery cechy osobowości tj. psychotyzm (P), neurotyczność (N), ekstrawersję (E) oraz kłamstwa (L). Czynnik kłamstwa (L) sprawdza jedynie wiarygodność testu, a nie odnosi się wprost do aspektów osobowości (zawyżone wyniki w niej sugerują tendencję podmiotu do ,upiększania” własnego wizerunku, a niskie do zaniżania samooceny i każą z ostrożnością podchodzić do wyników testu). Czynnik P mierzy nasilenie psychotyzmu, który określa tzw. „twardość charakterologiczną" podmiotu, czyli zdolność do bycia zimnym i wyrafinowanym (należy dodać, że w dużym stopniu osoby z wysokimi wynikami w tym czynniku są równocześnie ciepłe, delikatne i wrażliwe). Czynnik E obejmuje wymiar ekstrawersji (nasilenie wyników ujawnia tendencję podmiotu do otwartości, spontaniczności, do nieprzemyślanych zachowań) oraz introwersji (niskie wyniki: podmiot zamknięty w sobie, nieśmiały, zahamowany, skłonny do ciagłych autoanaliz). Ostatni czynnik N mierzy nasilenie neurotyzmu (wysokie wyniki ujawniają występowanie w podmiocie tendencji do przewrażliwienia, dużego napięcia emocjonalnego, niestabilności emocjonalnej, braku integracji osobowościowej oraz skłonności do zaburzeń afektywnych).

B. Skala Mistycyzmu (SM) R. Hooda. Psycholog amerykański, Hood w oparciu o konceptualizację rozumienia przeżycia religijnego przez Stace'a (1960) opracował narzędzie badawcze służące do pomiaru skłonności do przeżyć religijnych i percepcji tego, co uznaje osoba za boskie (Hood, 1975). Przez przeżycie religijne Hood rozumie doświadczenie obecności tego, co boskie, święte i odczucie jedności z nim. Niekoniecznie takie przeżycie musi odnosić się do Sacrum, może dotyczyć piękna, prawdy. Narzędzie to mierzy pewne skłonności do przeżyć religijnych o charakterze mistycznym danej osoby i określa jego strukturę. Test stanowią 32 twierdzenia, na które badani odpowiadają, zakreślając odpowiedzi punktowane w 5-stopniowej skali: $+2,+1,0,-1$ oraz -2 . 
Skale składają się z ośmiu czynników. Pierwsze siedem określa ogólne skłonności do przeżyć religijnych, ostatni - ósmy - czynnik ma charakter ściśle religijny, określa poczucie przeżycia obecności boskości u danej osoby. Czynnik - Stan Jaźni (J) określa poczucie utraty siebie, widziane jako wchłonięcie w coś większego od czystego empirycznego „Ja” $\mathrm{w}$ trakcie przeżycia religijnego. Zjednoczenie (Z) - człowiek postrzega siebie i rzeczywistość go otaczającą jako coś jednego. Wewnętrzna subiektywność (S) - czynnik ten odnosi się do określenia wewnętrznej subiektywności człowieka w postrzeganiu innych rzeczy. Czasowość - Przestrzenność (C-P), obejmuje czasowe i przestrzenne parametry przeżycia religijnego, które ma miejsce poza czasem i przestrzenią. Noetyczność (No) - określa zakres zdobytej wiedzy drogą intuicyjną. Niewysłowioność $(\mathrm{N})$ - czynnik ten określa niemożliwość słownego wyrażenia przeżycia religijnego. Doświadczenie nie może być ujęte w słowa z racji jego natury, a nie z powodu językowej nieudolności człowieka. Pozytywna efektywność (P) - ujawnia się w formie radości, olśnienia i poczucia szczęścia. Religijność (R) - określa wewnętrzne przekonanie człowieka o poczuciu bliskości przedmiotu religijnego, odnosi się do tego, co możemy nazwać święte, boskie (Kuczkowski, 1991).

W celu wyłonienia zmiennych niezależnych istotnych wyjaśniających wariancję zmiennych zależnych i określenia ich procentu zmienności użyto analizy wielokrotnej regresji (Guilford, 1964). Dla ukazania związku pomiędzy aspektami osobowości, branymi pod uwagę $\mathrm{w}$ obecnych badaniach, zastosowano analizę wariancji (ANOVA). w opracowaniu danych statystycznych posłużono się pakietem programów statystycznych SPSS.

\section{Opis grupy i sposób przeprowadzenia badań}

Badania przeprowadzono samodzielnie w grupach klasowych (około 20 osób). Miały one charakter anonimowy. Przebiegały one w dwóch etapach, w których młodzi ludzie wypełniali poszczególne testy. Grupa badawcza to uczniowie Zespołu Państwowych Szkół Plastycznych w Krakowie). Granice wiekowe znajdują się w przedziale pomiędzy 13 a 20 rokiem życia. $75 \%$ badanej młodzieży to kobiety, a reszta to mężczyźni. Badaniami objęto uczniów starszych klas (150 osób w wieku od 15 do 20 lat). Jedna czwarta (20\%) młodzieży deklaruje się jako wierzący i bardzo wierzący, około $50 \%$ jako przeciętnie wierzący, natomiast jedna trzecia (30\%) jako słabo albo bardzo słabo wierzący. Oznacza to, że grupa badawcza jest bardzo zróżnicowana i dokonana samoocena odpowiada faktycznemu stanowi.

\section{Wyniki badań wlasnych}

Zasadniczym celem tych badań było ukazanie powiązań nasilenia różnych cech osobowości młodzieży artystycznej z poziomem ich przeżyć religijnych (uczniowie Zespołu Państwowych Szkół Plastycznych w Krakowie N=200). Postanowiono uka- 
zać, które spośród zmiennych dotyczących nasilenia cech osobowości mają istotne oddziaływanie na przeżycia religijne młodzieży o uzdolnieniach artystycznych. Za wartości zmienne niezależne przyjęto zmienne otrzymane w Zrewidowanym Inwentarzu Osobowości (ZIO), zaś za zmienne zależne w Skali Mistycyzmu (SM).

A. Najpierw postanowiono ukazać, jakie jest nasilenie cech osobowości i przeżyć religijnych młodzieży żeńskiej i męskiej.

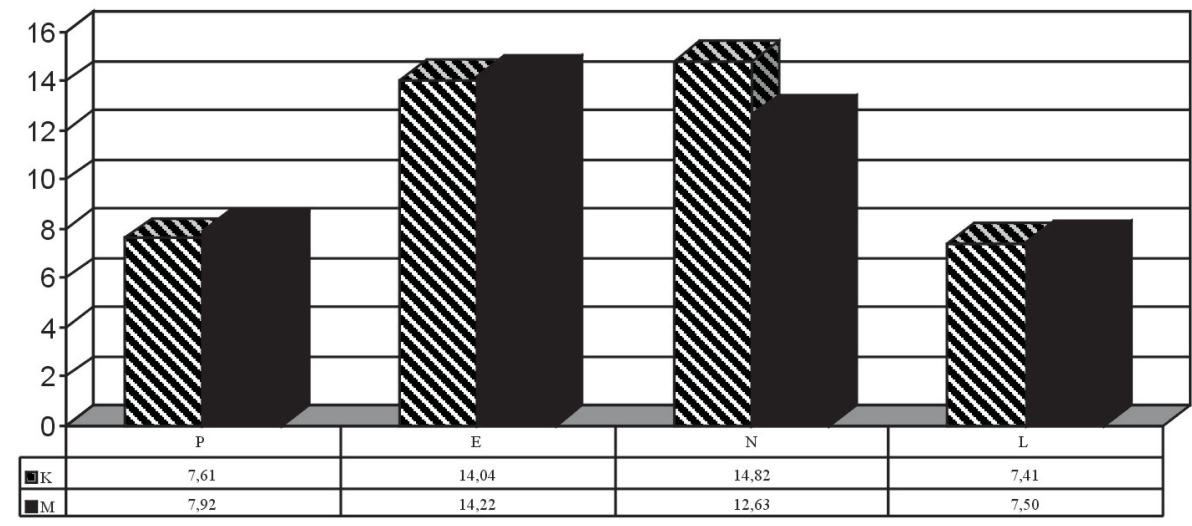

Wykres 1. Srednie arytmetyczne cech osobowości mężczyzn i kobiet uzyskane w Zrewidowanym Inwentarzu Osobowości (ZIO)

Zamieszczony wykres pokazuje, że badana młodzież posiada podwyższony poziom psychotyzmu (P) i neurotyzmu (N), co znaczy, że jest mało zrównoważona emocjonalnie, skłonna do zaburzeń emocjonalnych, ale równocześnie niezależna, przebojowa i „twarda mentalnie”. Osoby badane ujawniają średni poziom ekstrawersji (E), co sugeruje, że są przeciętnie otwarte, emocjonalnie dostępne, ale równocześnie nieco zamknięte w sobie, wrażliwe i skłonne do wewnętrznych dialogów. Ponadto charakteryzują się nieco podwyższonym nasileniem kłamstwa (L), a to wskazuje na fakt, że posiadają przeciętnie dobry wgląd w siebie (mają tendencje do zawyżania samooceny).

Powyższy rozkład wyników ujawnia, że brane pod uwagę aspekty osobowości różnicują istotnie kobiety i mężczyzn tylko w skali oznaczającej nasilenie neuroty$\mathrm{zmu}(\mathrm{N})(\mathrm{F}=3,234, \mathrm{p}=0,004)$. Kobiety ujawniają podwyższony poziom neurotyzmu w stosunku do mężczyzn. Oznacza to, że kobiety w tym wypadku są mniej zrównoważone emocjonalnie i bardziej skłonne do zaburzeń niż mężczyźni. W pozostałych wymiarach osobowości zauważalne są jedynie pewne tendencje. Kobiety są bardziej „miękkie charakterologicznie” niż mężczyźni, co więcej bardziej skłonne do introwersji oraz do negatywnej samooceny. 


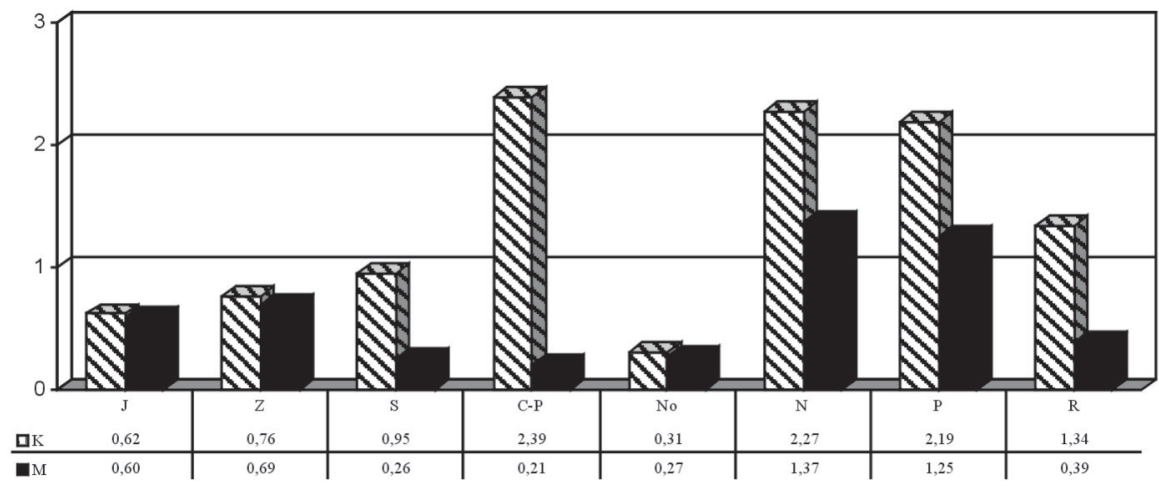

Wykres 2. Średnie arytmetyczne przeżyć religijnych kobiet i mężczyzn uzyskane w Skali Mistycyzmu (SM)

Kobiety i mężczyźni ujawniają zawyżoną skłonność do przeżyć religijnych i ich złożoną strukturę. Kobiety jak i mężczyźni charakteryzują się podwyższonym poziomem pozytywnej afektywności (P), niewysłowioności $(\mathrm{N})$ oraz w pozaczasowości i pozaprzestrzenności (C-P). Oznacza to, że u badanej młodzieży występują bardzo intensywne uczucia radości i euforii, poczucie utraty rzeczywistości i czasu oraz brak zdolności do werbalizacji tych przeżyć. Ujawniają średni poziom w dziedzinie wewnętrznej subiektywności (S) oraz religijności (R). Sugeruje to, że badane osoby nie upatrują zbyt łatwo w rzeczywistości elementów subiektywności oraz nie są zawsze przekonane o bliskości przedmiotu religijnego. Najniższy poziom ujawniają badane osoby w wymiarze wchłonięcia (W) i zjednoczenia (Z), co oznacza, że osoby te pomimo euforyczności zachowują dystans do odczuwanych przeżyć i nie ulegają całkowicie doznawanym intensywnym emocjom. Relatywnie najsłabszy poziom ujawniają w zakresie noetyczności (No). Można przypuszczać, że badana młodzież ma wątpliwości co do realności zdobytej wiedzy w trakcie przeżycia religijnego.

Istotne różnice występują pomiędzy mężczyznami a kobietami jedynie pod względem ogólnej zdolności do przeżyć religijnych $(\mathrm{M})(\mathrm{F}=0,081$, $\mathrm{p}=0,033)$ oraz w sferze czasowości i przestrzenności $(\mathrm{C}-\mathrm{P})(\mathrm{F}=0,084, \mathrm{p}=0,004)$. Oznacza to, że kobiety są bardziej skłonne do przeżyć religijnych, łatwiej w trakcie tychże przeżyć tracą poczucie rzeczywistości i czasu niż mężczyźni. W innych aspektach przeżycia religijnego pojawiają się pewne tendencje zwyżkowe, gdzie kobiety ujawniają wyższe skłonności do przeżyć religijnych we wszystkich aspektach oprócz jednego tj. poczucia „wchłonięcia” (J). W tym ostatnim aspekcie mężczyźni w takim samym stopniu jak kobiety zachowują samoświadomość, kiedy doświadczają owo „pochwycenie” przez coś większego od empirycznego ,ja”.

B. Następnie postanowiono ukazać, które spośród wartości dotyczących cech osobowości mają istotne oddziaływanie na poziom przeżyć religijnych u kobiet. 
Tabela 1. Istotne zmienne niezależne dotyczące nasilenia cech osobowości (ZIO) i wyjaśniające wariancję przeżyć religijnych (SM). Wyniki analizy regresji wielokrotnej u kobiet

\begin{tabular}{|l|c|c|c|c|}
\hline \multicolumn{1}{|c|}{ Zmienne } & B & Beta & $\mathbf{t}$ & $\mathbf{p}$ \\
\hline Niezależna (L) & 0,205 & 0,227 & 2,486 & 0,014 \\
\hline Zależna (No) & $\mathrm{r}=0,227$ & $\mathrm{r}^{2}=0,051$ & $\mathrm{~F}=6,179$ & $\mathrm{p}=0,014$ \\
\hline Niezależna (P) & 0,317 & 0,275 & 2,931 & 0,004 \\
\hline Zależna (N) & $\mathrm{r}=0265$ & $\mathrm{r}^{2}=0,070$ & $\mathrm{~F}=8,514$ & $\mathrm{p}=0,004$ \\
\hline Niezależna (N) & $-0,132$ & $-0,195$ & $-2,122$ & 0,036 \\
\hline Zależna (P) & $\mathrm{r}=0,195$ & $\mathrm{r}^{2}=0,038$ & $\mathrm{~F}=4,501$ & $\mathrm{p}=0,036$ \\
\hline
\end{tabular}

Trzy zmienne niezależne dotyczących różnych cech osobowości kobiet oddziałują na trzy elementy struktury przeżycia religijnego. Cechami tymi są: kłamstwo (L), które wywiera wpływ na noetyczność (No) $(\mathrm{p}=0,014)$, psychotyzm (P), który wpływa na poczucie niewysłowioności $(\mathrm{N})(\mathrm{p}=0,004)$ oraz neurotyzm $(\mathrm{N})$, które wywiera wpływ na pozytywną afektywność $(\mathrm{P})(\mathrm{p}=0,036)$. Nasilenie poziomu kłamstwa wyjaśnia 5\% wariancji poczucia noetyczności. Nasilenie cechy psychotyzmu wyjaśnia 7\% zmienności niewysłowioności. Ponadto nasilenie neurotyzmu wyjaśnia 4\% wariancji pozytywnej afektywności. Wpływ cech osobowości jest słaby i dodatni.

Oznacza to, że u młodzieży żeńskiej im wyższa jest samoocena, przekonanie o własnej wartości, twardość myślenia i reakcji (nasilenie kłamstwa i psychotyzmu), tym silniejsze przekonanie o realności poznawanych treści w trakcie doznań oraz większa niezdolność do werbalizacji doznawanych przeżyć religijnych. Natomiast im silniejsze zamknięcie się w sobie, większe przewrażliwienie, silniejsze tendencje do zaburzeń emocjonalnych (neurotyzm), tym silniejsze uczucia euforii i radości towarzyszące przeżyciom religijnym.

Tabela 2. Istotne zmienne niezależne dotyczące nasilenia cech osobowości (ZIO) i wyjaśniające wariancję przeżyć religijnych (SM). Wyniki analizy regresji wielokrotnej u mężczyzn

\begin{tabular}{|l|c|c|c|c|}
\hline \multicolumn{1}{|c|}{ Zmienne } & B & Beta & t & p \\
\hline Niezależna (E) & 0,292 & 0,462 & 3,214 & 0,003 \\
\hline Zależna (J) & $\mathrm{r}=0,462$ & $\mathrm{r}^{2}=0,214$ & $\mathrm{~F}=10,330$ & $\mathrm{p}=0,014$ \\
\hline Niezależna (E) & 0,188 & 0,322 & 2,096 & 0,043 \\
\hline Zależna (Z) & $\mathrm{r}=0,322$ & $\mathrm{r}^{2}=0,104$ & $\mathrm{~F}=3,393$ & $\mathrm{p}=0,043$ \\
\hline Niezależna (E) & 0,226 & 0,316 & 2,125 & 0,040 \\
\hline Zależna (C-P) & $\mathrm{r}=0,326$ & $\mathrm{r}^{2}=0,106$ & $\mathrm{~F}=4,516$ & $\mathrm{p}=0,040$ \\
\hline
\end{tabular}

Jedna zmienna niezależne dotycząca ekstrawersji oddziałuje na trzy elementy struktury przeżycia religijnego u młodzieży męskiej. Cechą tą jest ekstrawersja, 
która wywiera wpływ na poczucie Jaźni $(\mathrm{J})(\mathrm{p}=0,003)$, zjednoczenia $(\mathrm{Z})(\mathrm{p}=0,043)$ i czasoprzestrzenności $(\mathrm{C}-\mathrm{P})(\mathrm{p}=0,040)$. Nasilenie cechy ekstrawersji wyjaśnia $21 \%$ wariancji poczucia Jaźni, 10\% zmienności poczucia zjednoczenia i 11\% zmienności czasoprzestrzenności. Wpływ tych zaburzeń jest dodatni i przeciętny.

Oznacza to, że im silniejsze są u mężczyzn tendencje do otwartości, spontaniczności, impulsywności, tym jest silniejsza utrata poczucia siebie przy zachowanej świadomości i stopień zjednoczenia z przedmiotem doznań. Ponadto zaznacza się silniejsze odczuwanie, że doświadczenie przebiega poza czasem i przestrzenią.

\section{Dyskusja wyników}

Podjęta procedura badawcza i psychologiczna analiza materiału empirycznego uzyskana wśród młodzieży o uzdolnieniach artystycznych potwierdza postawione hipotezy badawcze w niektórych aspektach:

1. Nasilenie cech osobowości wptywa istotnie na dynamikę przeżyć religijnych we wszystkich wymiarach - hipoteza znalazła słabe potwierdzenie (w przypadku kobiet i mężczyzn wpływ na 3 spośród 8 wymiarów). U kobiet istotny wpływ dotyczy trzech wymiarów przeżyć religijnych tj. noetyczności, niewysłowioności i pozytywnej afektywności (wpływ jest słaby i pozytywny). U mężczyzn dotyczy również trzech wymiarów, ale innych niż u kobiet, tzn. Jaźni, poczucia zjednoczenia i czasoprzestrzenności (wpływ przeciętny i pozytywny). Oznacza to, że w przypadku zarówno kobiet, jak i mężczyzn cechy osobowości odgrywają słabą rolę w dynamizowaniu przeżyć religijnych (dotyczą tylko niektórych aspektów przeżyć religijnych). W przypadku mężczyzn wpływ ten jest wprawdzie silniejszy, ale również ograniczony.

2. Wszystkie cechy osobowości wywieraja istotny wptyw na przeżycia religijne mtodzieży artystycznej - hipoteza znalazła również słabe potwierdzenie, zwłaszcza u mężczyzn. W przypadku młodzieży żeńskiej wpływ ten jest bardziej wszechstronny (3 wymiary 4), podczas gdy u młodzieży męskiej bardziej ograniczony (1 cecha spośród 4). $\mathrm{U}$ kobiet ważną rolę $\mathrm{w}$ dynamizowaniu przeżyć religijnych odgrywa poziom kłamstwa, neurotyzmu i psychotyzmu a u mężczyzn tylko ekstrawersji (u obu płci wpływ dodatni). Sugeruje to, że w przypadku kobiet ważną rolę w nasilaniu przeżyć religijnych odgrywają różne wymiary osobowości a mężczyzn słabszą (ograniczoną do jednej cechy).

Wydaje się, że postawiony problem badawczy został w dużej mierze rozstrzygnięty. Ukazano bowiem wszechstronny wpływ wszystkich cech osobowości (u młodzieży żeńskiej i męskiej razem wszystkie 4 cechy osobowości wchodzą w relacje z przeżyciami religijnymi - u kobiet 3 na 4 możliwe a u mężczyzn 1 na 4). Oznacza to, że nasilenie cech osobowości - zgodnie z przedstawionymi założeniami teoretycznymi wpływa w istotnym stopniu na intensywność przeżyć religijnych młodzieży. Wpływ cech osobowości na przeżycia religijne w przypadku kobiet jest wszechstronny, ale słaby. Natomiast u mężczyzn bardziej ograniczony (1 cecha osobowości), ale za to silniejszy. Można z tego wywnioskować, że osiągnięte rezultaty badawcze pokazują, 
iż zarówno u kobiet, jak i u mężczyzn nasilenie cech osobowości jest ważnym czynnikiem modyfikującym przeżycia religijne.

Należy podkreślić, że ujawniony wpływ cech osobowości jest zupełnie odmienny w przypadku kobiet niż mężczyzn. U kobiet intensywność przeżyć religijnych jest uzależniona od poziomu psychotyzmu, neurotyzmu i kłamstwa, a u mężczyzn od poziomu ekstrawersji. Można więc powiedzieć, że płeć stanowi ważny czynnik warunkujący przeżycia religijne (brak jest jednak w tym zakresie wyników badań konfirmacyjnych).

Uzyskane w niniejszych badaniach wyniki dotyczące mężczyzn są podobne do innych, w których wykazano istotny związek nasilenia ekstrawersji z poziomem przeżyć religijnych (Francis, Thomas, 2005). Oznacza to, że w przypadku młodzieży męskiej ważną rolę $\mathrm{w}$ dynamizowaniu przeżyć religijnych odgrywają takie aspekty osobowości, jak otwartość mentalna, impulsywność, przebojowość, asertywność i towarzyskość. Ujawnia to też, że mężczyźni zamknięci w sobie, wysoce refleksyjni, mało towarzyscy, zdolni do pogłębionego wglądu w siebie oraz wrażliwi na ból i cierpienie są w małym stopniu zdolni do przeżyć mistycznych. Zapewne koncentracja na sobie, krytycyzm i refleksyjność blokują emocjonalny wymiar ich doświadczeń. Być może dlatego, że mężczyźni cenią takie aspekty introwersji, jak refleksyjność, krytycyzm, obiektywizm i racjonalizm ( $w$ tej próbce badawczej nie występują istotne różnice pomiędzy mężczyznami a kobietami pod względem nasilenia ekstrawersji - nawet nieco bardziej ekstrawersyjni są mężczyźni), które naturalnie blokują emocjonalną spontaniczność. Dlatego właśnie rozwój odmiennych tendencji, tj. ekstrawersyjnych, umożliwia im odblokowanie spontanicznych pokładów osobowości dynamizujących przeżycia religijne.

W przypadku młodzieży żeńskiej można mówić o nowatorstwie uzyskanych rezultatów (brak badań potwierdzających). Wobec braku takich wyników badań, które by były w zgodzie z uzyskanymi w niniejszych badaniach, trudno wyciagać bardziej wiążące wnioski. Należy jednak dodać, że uzyskane wyniki nie są odmienne od innych w tym zakresie. W niektórych badaniach wykazano wielokrotnie, że istnieje pozytywny związek pomiędzy zdrowiem psychicznym a intensywnością przeżyć mistycznych (por. Forbes, 2004; Hood, 1975, 1977, 1995; Hood i in., 2001; Hay, Morrisy, 1978; Ludwig, 1985; Mathes, Zevon, Roter, Joerger, 1982; Radoń, Głaz, 2006; Wachholtz1, Pargament, 2005). Biorąc pod uwagę uzyskane rezultaty badawcze $\mathrm{w}$ tych badaniach, należy stwierdzić, że w przypadku kobiet występują dwa przeciwstawne dynamizmy wpływu zdrowia psychicznego na przeżycia religijne: $\mathrm{z}$ jednej strony nasilenie objawów zdrowia psychicznego (nieco podwyższona samoocena oraz twardość mentalna i przebojowość) wpływa na intensyfikację przeżyć religijnych, a z drugiej osłabienie tego zdrowia (podwyższone przewrażliwienie, skłonność do zaburzeń afektywnych). Ten drugi dynamizm stanowi zaprzeczenie wyników cytowanych powyżej badań. Jednak otrzymany efekt w tym aspekcie może być zrelatywizowany faktem, że dotyczyły młodzieży przechodzącej niestabilny i pełen kryzysów okres adolescencji oraz elitarnej próbki o cechach artystycznych (podwyższone nasilenie neurotyzmu w całej próbce oraz u młodzieży żeńskiej w stosunku do męskiej). 
Podkreślić należy, że udowodniono, iż wpływ cech osobowości na przeżycia religijne zarówno po stronie czynnika modyfikującego (zmienna zależna, tj. przeżycia religijne), jak i modyfikowanego (zmienna niezależna, tj. cechy osobowości) jest ograniczony i słaby. Ten wpływ jest słaby zwłaszcza u mężczyzn po stronie czynnika modyfikującego (przeżycia religijne). Uzyskane rezultaty sugerują więc, że zwłaszcza w przypadku mężczyzn, ale również i u kobiet (w mniejszym co prawda stopniu), obok cech osobowości inne aspekty osobowości odgrywają ważną rolę w dynamizowaniu przeżyć religijnych.

Uzyskane rezultaty badawcze prowadzą do generalnego wniosku, iż cechy osobowości w rozumieniu Eysencka (typy) odgrywają raczej słabą i mało wszechstronną rolę w dynamizowaniu przeżyć religijnych młodzieży artystycznej. Może to sugerować, że w dziedzinie stymulacji przeżyć religijnych propozycja teoretyczna Eysencka - prowadząca do pewnego celowego uproszczenia obserwowanych aspektów osobowości - nie jest szczególnie trafna. Widocznie w dziedzinie przeżyć religijnych występują pewne specyficzne aspekty osobowości, których uchwycenie możliwe jest przy zastosowaniu innych narzędzi badawczych oraz propozycji teoretycznych. Uzyskiwane na całym świecie rezultaty badawcze nie pozwalają na wyciagnięcie wniosku, że przeżycia religijne stanowią niezależny od uwarunkowań osobowości epifenomen, który trudno badać (uzyskuje się wyniki istotne statystycznie), a więc należy stwierdzić, że być może stosowane narzędzia badawcze wynikające z konkretnych propozycji teoretycznych $w$ tej dziedzinie nie są wielce relewantne.

Przeprowadzone badania stanowią, jak widać po cytowanej literaturze, dopiero wstęp do bardziej pogłębionych studiów dotyczących współzależności (wpływu) pomiędzy cechami osobowości a intensywnością przeżyć religijnych. Również wyniki tych badań dotyczące osób z wysokimi zdolnościami artystycznymi (Radoń, Głaz, 2006) nie prowadzą do klarownych wniosków (słaby i mało wszechstronny wpływ cech osobowości na przeżycia religijne, niezbyt spójne wyniki w przypadku młodzieży żeńskiej, natomiast spójne z wynikami innego badania w przypadku młodzieży męskiej).

W związku z tym pojawia się potrzeba przeprowadzenia kolejnych badań, w których należałoby na pierwszym miejscu uwzględnić inne narzędzia badawcze do eksploracji głębszych pokładów osobowości (inne narzędzia badawcze wynikające z innych koncepcji osobowości). Byłoby interesujące przebadać inną próbkę osób, u której nie byłoby podwyższonych wskaźników neurotyzmu (szczególnie u kobiet), ponieważ szczególnie ten aspekt mógł mieć wpływ na uzyskane rezultaty. Jak się też wydaje, należy postulować uwzględnienie większego spektrum cech osobowości w diagnozowaniu osobowościowych uwarunkowań przeżyć mistycznych. Bardzo interesujące, ale wymagające dużych nakładów, byłyby badania idiograficzne (bardzo rzadko przeprowadzane w dziedzinie przeżyć religijnych). 


\section{Bibliografia}

Alexander C. N., Boyer R. W., Alexander V. K. (1987), Higher states of consciousness in the Vedic Psychology of Maharishi Mahesh Yogi: a theoretical introduction and research review, Modern science and Vedic science, t. 1, s. 89-132.

Batson C. D., Schoenrade P., Ventis W. L (1993), Religion and the individual. a social-psychological perspective, Oxford University Press, New York.

Bazylak J. (1984), Postawy religijne młodzieży i ich zwiazki z wybranymi elementami osobowości, Warszawa: Akademii Teologii Katolickiej.

Capps D. (1999), From mystical moment to therapeutic method: Connections between psychology of religion and pastoral counseling, Pastoral Psychology, Vol. 48(1), s. 23-44.

Chlewiński Z. (1973), Diagnostyka przynależności do grupy na podstawie cech osobowości. Zastosowanie sekwencyjnej analizy dyskryminacyjnej, Roczniki Filozoficzne 11, s. 5-29.

Chlewiński Z. (1981), Personality and attitude towards religion In Poland, Personality and Individual Differences 2, s. 243-245.

Chlewiński Z. (1987), Postawy a cechy osobowości, Towarzystwo Naukowe KUL Lublin.

Eysenck H. J. (1947), Structure of personality, Praeger, New York.

Eysenck H. J., Eysenck S. B. G. (1969), Personality structure and measurement, Knapp, San Diego.

Forbes F. (2004), Anton Boisen, pioneer on the study of mental disorder and religious experience: a critical review of the literature, Dissertation Abstracts International Section A: Humanities and Social Sciences, t. 65(1-A), s. 170.

Francis L. J., Thomas T. H. (2005), Mystical orientation and personality among Anglican clergy, Pastoral Psychology 45(2), s. 95-105.

Głaz S. (1995), Zagadnienie doświadczenia religijnego, WAM, Kraków.

Głaz S. (1996), Intensywność doświadczenia religijnego a koncepcja siebie, WAM, Kraków.

Głaz S. (2003), Wpływ zmiennych egzystencjalnych na skutki przeżycia religijnego, Czasopismo Psychologiczne, 1, s. 111-132.

Głaz S. (2004), Wyznaczniki przeżycia religijnego u młodzieży akademickiej, Studia Psychologia, t. 5, s. 81-102.

Hay D. (1979), Religious experience amongst a group of post-graduate students. A qualitative study, Journal for Scientific Study of Religion, t. 18, s. 164-184.

Hay D., Morrisy A. (1978), Reports of ecstatic, paranormal or religious experience in Great Britain and the United States. a comparison of trends, Journal for Scientific Study of Religion, t. 17, s. 255-268.

Hood R. W., (1975), The construction and preliminary validation of a measure of reported mystical experience, Journal for the Scientific Study of Religion, t. 14, s. 29-41.

Hood R. W. (1995), Handbook of religious experience, Birmingham: Religious Education Press.

Hood R. W., Ghorbani N., Watson P. J., Ghramaleki A. F., Bing, Mark N., Davison H. Kristl M., Ronald J., Williamson W. P. (2001), Dimensions of the Mysticism Scale: Confirming the Three-Factor Structure in the United States and Iran, Journal for the Scientific Study of Religion Vol. 40:4, s. 691-705.

Hood R. W., Spilka B., Hunsberger B., Gorsuch R. (1996), Psychology of Religion: An empirical approach, Guilford, New York.

Ludwig A. (1969), Altered states of consciousness, Archives of General Psychiatry Vol. 15, s. $225-234$.

Mathes E. W., Zevon M. A., Roter P. M., Joerger S. M. (1982), Peak experience tendencies: scale development and theory testing, Journal of Humanistic Psychology, t. 22 (3), s. 92-108. 
Mercer C., Durham Th. W. (1999), Religious mysticism and gender orientation, Journal for the Scientific Study of Religion, t. 38 (1), s. $175-182$.

Paloutzian R. F. (1996), Invitation on the psychology of religion, Allyn and Bacon, Boston.

Pospiszyl K. (1992), Psychopatia, Wyd. Naukowe PWN, Warszawa.

Prężyna W. (1981), Funkcja postawy religijnej w osobowości człowieka, Wyd. Naukowe KUL, Lublin.

Radoń S., Głaz, S. (2006), Przeżycia religijne młodzieży uzdolnionej artystycznie, WAM, Kraków.

Schlesing B. (2005), Spirituality in the Developmental Stages of Adolescence, w: Cox R. H., Ervin-Cox B. (red.), Spirituality and psychological health, Colorado School of Psychology Press, s. 75-85.

Szymołon J. (1998), Lęk i fascynacja. Osobowościowe korelaty lęku i fascynacji w przeżyciu religijnym, Redakcja Wydawnictw KUL, Lublin.

Wachholtz A. B., Pargament K. I. (2005), Is Spirituality a Critical Ingredient of Meditation? Comparing the Effects of Spiritual Meditation, Secular Meditation, and Relaxation on Spiritual, Psychological, Cardiac, and Pain Outcomes, Journal of Behavioral Medicin, t. 28, s. 369-384.

\section{Personality traits on religious experiences among artistically gifted young people (Summary)}

This article examines the role of the personality traits on religious and mystical experiences among artistically gifted young people. Ss ( $\mathrm{N}=150$ aged $15-20$ yrs) were administered questionnaire measures of four personality traits (intro-extraversion, psychoticism, neuroticism and lie - Eysenck Personality Questionaire) and eight of religious experience (Hood's Mysticism Scale). Multiple regression were used. The results of psychological analysis suggests that the personality traits are the important factors on religious and mystical experience. Women's mystical experiences are influenced by higher intensification of toughminded ( $p s y$ choticism), superior compliance to emotional disturbances (neuroticism), positive self-esteem (lie) and men's - by sociability and spontaneity (extraversion). The results suggest that biopsychological conditioning personality traits may be important variables to consider within the theory of religious experience. 